\title{
Analysis of the workload imposed on the workers of the imprint and cutting/welding sectors of a flexible packaging manufacturer
}

\author{
L. B. de M. Guimarães ${ }^{\mathrm{a}^{*}}$, S.L.R. Pessa ${ }^{\mathrm{b}}$ and C. Biguelini ${ }^{\mathrm{a}}$ \\ ${ }^{a}$ Graduate Program in Industrial Engineering, Federal University of Rio Grande do Sul, Av. Osvaldo Aranha 99 \\ $5^{o}$ andar,Porto Alegre, RS, 90035-190,Brazil,_E-mail: liabmg@gmail.com; ceciliabiguelini@gmail.com \\ ${ }^{b}$ Department of Mechanical Engineering, Federal Technological University of Paraná, Via do Conhecimento, $\mathrm{km}$ \\ 1,Pato Branco,PR, 85503-390,Brazil, E-mail: slpessa@utfpr.edu.br
}

\begin{abstract}
This article presents a study on the evaluation of the workload imposed to workers of two sectors of a flexible packaging manufacturer that operates in three shifts. The workers are allocated in one of the shifts (morning, evening and night shifts) without evaluation of their chronotype and/or social needs. The Imprint sector has a more dynamic work, which is done only by man due to the effort demanded by handling loads. The work in the Cutting/Welding sector is static, done mainly by women. The results showed that the overall workload was the same in the Imprint and Cutting/Welding sectors, because physical effort for load handling is higher in the former but the latter involves high static load. The levels of urinary catecholamines and salivary cortisol were consistent with the workers biological clock showing that none of the workers changed his/her biological cycle to accommodate to the time of the shift schedule.
\end{abstract}

Keywords: shiftwork, workload, physiological parameters, subjective parameters.

\section{Introduction}

The negative impacts of night and shiftwork on health (more fatigue, sleep deprivation and pathologies), familiar and social unbalance as well as workers efficiency has been widely discussed in the literature. Night work determines that workers meals are often irregular, taken in unusual hours, very different from the schedules the worker has in the non working days or during daytime work. The alterations on resting hours impact on the biological rhythm and the worker cannot control the effects on both physical and cognitive functions because they are synchronized with the biological rhythm of sleep and vigilance [22]. The consequences are insomnia, irritation, excessive sleepiness during the day, lethargy during night work, continuous fatigue, disruption of digestive treat functioning and increase in cardiovascular diseases $[3,25,45]$. Focused attention is reduced due to sleepiness, open eyes involuntary naps are frequent without being perceived by the worker, accident's risk increase, and production discontinues. Road accidents, for example, are more likely during night $[3,67]$. Higher mortality rate was found in fixed night shift Imprint workers [65].

The adverse effects of night and shiftwork might be minimized by reducing the number of night work and compensating with more time offs [40,43-44]. More than three consecutive night shifts should be avoided [3] in order to generate more time for recovering from fatigue, sleep deprivation and biological alterations: the more night shifts, the worse the quality of sleep [23]. Work schedule should be well defined by the type of system, beginning and end of each shift, duration and frequency, the number of

* Corresponding author. Email: liabmg@gmail.com

tel: +55 (51) 3308-3948 fax: +55 (51) 3308-4007 
working days, pauses, number of free days and compensation for working days [41].

Although night work performance is generally considered inferior to daytime work performance $[21,24]$, comparison among shifts is difficult to make due to the many variables involved, such as work environment, type of work, pressure for production, bonus payment etc [54]. Besides, researches focus on schedules based on general ergonomics guidelines but forget about the worker's capabilities and procedures to carry out the tasks during day or night [66]. The assumption that what is reasonable for daytime work is also reasonable for night work is false as is the assumption that, chronobiologicaly, human beings cannot be efficient at night due to a reduction of attention. Workers adopt strategies both individually and collectively to cope with the constraints imposed by unusual working hours [66]. Besides, the impacts of night and shiftwork should not be evaluated considering only the worker individually because social matters are also involved $[43,62,66]$. Therefore, people should have more autonomy for organizing their working schedule and choose their journey model $[42,44]$. Considering both the individual differences and needs, people should be asked to perform tasks in accordance to their capabilities during morning, evening or night in order not to get overloaded and negatively impact production.

Most studies focus the impacts of night and shiftwork on the quality of sleep $[4-5,7,16,22,24-$ $25,39,49-50,53,55-56,59,61,63-64]$ on the sleep deprivation and its relation to accidents $[6,43]$, mortality $[8,47]$ and both psychophysical and psychosocial effects of shiftwork [1-2]. Other studies focus on the nutritional and metabolic conditions $[9,57]$ and health and general problems $[8,26,46-47,58]$. Studies are transversal, based on databases from large enterprises of the transportation [39,50,55,59], petrochemical $[21,22]$ and chemical $[40,53]$ sectors, relating night and shiftwork with illnesses and absenteeism, not necessarily changing the work organization. No longitudinal studies (i.e. evaluating a same population for a long time) were done so far because they are difficult to pursue [15].

While most studies on night and shiftwork focus on people's health, industrial engineering studies do not focus either on health or ergonomics but on production and complying with legislation. Ergonomic studies on the workers satisfaction with their shiftwork were done in a shoe component manufacturer [1], in a mailing company [11], in a graphics industry [12], in a call center [17], in a steel metallurgy company [31] and in an oil transportation company [51].
In order to contribute for the night and shiftwork literature in ergonomics, this study aimed to evaluate the impact of shiftwork on the workload perceived by 85 employees from two sectors of a packaging manufacturer company in the state of Parana, Brazil, which operates in three fixed shifts. Another paper presents the opinion of these same workers about the shiftwork and the work carried out in the Company.

\section{Method}

Subjective evaluation of workload was based on the Macroergonomic Work Analysis (MA) work content questionnaire [30] and an adaptation of the NASA-TLX [32] questionnaire, both answered by 85 workers (mean age 27 years old): 42 male workers from the three shifts of the Imprint (I) sector and 43 (39 being women) from the Cutting/Welding (C/W) sector of the Company. A differential of this study is that physiological evaluation was also carried out to evaluate stress based on: 1) levels of urinary catecholamine and the levels of salivary steroid hormone cortisol, measured on the beginning and at the end of the work journey, on two dates, from 23 volunteers (10 from the I sector and 13 (all women) from the $\mathrm{C} / \mathrm{W}$ sector), from the three shifts of each sector; 2) heart frequency (HF) and arterial pressure of the 23 workers, measured on two dates, four times each day (in the beginning, two in the middle and one at the end of the work journey). Heart frequency and arterial pressure were recorded by portable Geratherm KP-6310 monitors. Salivary samples $(10 \mathrm{ml})$ were collected with appropriate cotton sticks, by the researchers. The 23 volunteers gave the researches the urinary samples. These samples were delivered to the laboratory for analysis, after the end of the journey. All participants signed a consent form.

Environmental data (noise, temperature and humidity) were gathered for evaluation of their impact on the workers. Data were collected four times in a day, in the same two different dates of the physiological measurements.

The results were analyzed by descriptive statistics and non-parametric statistical tests because data did not display normal distribution. The correlation between the subjective and physiological results was evaluated by Spearman test; comparison of the physiological data (urinary levels of catecholamine and the levels of salivary cortisol) before and after the journey was made by Wilcoxon test. Friedman test was used to evaluate more than two paired variables 
(heart frequency and arterial pressure in four different moments in different days). Comparison of the responses among the three shifts of each sector was done by Kruskal-Wallis test. The results with a statistical difference (significant to p-value $<0.10$ ) were analyzed with a non-parametric comparison test. The Mann -Whitney U test was used to compare the results from the two sectors.

\section{Results}

\subsection{The work in the imprint and cutting/welding sectors}

The shifts in the Company are fixed: the morning one from 05:30 AM to 1:50 PM, the evening one from 1:45 $\mathrm{PM}$ to $10: 05 \mathrm{PM}$ and the night one from 10:00 PM to 05:35 AM. Temperature in the data collection dates varied from $12.7^{\circ} \mathrm{C}$ e $23.3^{\circ} \mathrm{C}$ below the discomfort limit in Annex 3 of norm NR15 [13] for the type of evaluated tasks. Noise varied between 82 $\mathrm{dB}(\mathrm{A})$ and $86,3 \mathrm{~dB}(\mathrm{~A})$, above the comfort limit of 80 $\mathrm{dB}(\mathrm{A})$ for 8 hours continuous work [28]. All workers use ear protectors.

The work in the I sector is done by 87 male workers (in the three shifts) in teams of 3 to 4 workers. It comprises the activities of machines setup, machines adjustments, quality control of the packaging during the imprint process, measurements of paints viscosity, cleaning and organization of machines and the sector, and production follow-up. They have tasks of more cognitive load (such as evaluating the production orders, and analysis of the quality of printed packaging samples collected during production) and more physical load (such as carrying the support axis of the off set machines and bobbins of finished products every 25 minutes by two workers). Work is more dynamic than static, done around the machines, always in a standing position.

The work in the C/W sector is done by 146 workers (in the three shifts) in 41 machines. Work comprises the activities of checking, selecting and bailing the products, at the pace of the machines. Eventually, it is necessary to adjust and/or correct some products and the centralization of the machines. At the end of the journey, they change the bobbins (with the help of a male worker), clean the machines and take note of the production and waste in the control form. Work is predominantly static, done in front of the machines, always in a static standing position.

\subsection{Physiological evaluation of workload}

\subsubsection{Salivary cortisol}

The levels of cortisol can be used as an index of stress since its secretion pattern changes in case of depression, psychological and physiological stress such as physical exercise and high temperatures. Its secretion pattern varies among people but tend to be constant for the same person [36-37]. The Wilcoxon test for paired data, considering the measurements of cortisol at the start and end of the journey in two dates (Table 1), showed significant difference between start and end data both in the Imprint $(\mathrm{p}=0.011$ on day 1 and $p=0.005$ on day 2 ), and in the Cutting/Welding sector $(\mathrm{p}=0.005$ on day 1 and $\mathrm{p}=0.004$ on day 2). The cortisol levels at the start of the journey are more than twice the levels at the end of the journey in the three shifts of the two sectors. This is in agreement with the circadian variation of cortisol, i.e., higher levels in the morning with a sharp increase at 6:00 AM, decreasing between 9:00 PM and 12:00 PM, with high variability, and a decrease in the night with low variability [36-37]. However, Hennig et al. [37] found an effect of the night shift in 24 nurses on the fifth night of nightshift as the cortisol secretion at 9:00 PM exceeded the concentration found at 6:00 AM in 18 nurses. The higher levels at night indicated a reversion of the circadian rhythm, i.e., adaptation of the workers to the nightshift. In this study, the cortisol levels at the start and end of the journey, in the two sectors, are higher in shift 1 , lower in shift 2 and even lower in shift 3 following the expected cortisol behavior for the time of day. Therefore, there was no reversion of cortisol secretion, no reversion of the circadian cycle i.e., there was no physiological adaptation to the shift.

\subsubsection{Heart frequency and arterial pressure}

Heart frequency (HF) is often used as a measurement of overall workload imposed by a given task on the worker, varying in accordance to both physical and mental stress, since the response to a given effort depends on physiological mechanisms that regulate it at an appropriate level of work [29,36]. In the beginning of work, there is an immediate increase in HF and arterial pressure (PAS, PAD e PAM), which tend to reach a certain level during work $[38,48]$.

$\mathrm{HF}$ increases when work is done with the upper limbs, when work is static (i.e. muscular isometric contraction), when environmental conditions are unfavorable (i.e., noisy, humid, hot) and under emotional stressful situations [10,29]. Because HF varies 
with individual characteristics, such as age, sex, state of fatigue, mood, physical fitness, preparedness for work and time of day [29], the loading of one and the same task is perceived differently and, therefore, responded to in different ways [18].

In order to reduce the effect of individual variability, Grandjean [29] suggests the use of the heart rate at work, or work pulse (WP), defined as the difference between the mean heart rate (HF) during work (working pulse), and the heart rate at rest (resting pulse) recorded with the subject seated, in terms of the number of beats per minute. 35 WP for men and 30 WP for women are the limits to be used in situations of continuous work [29]. Other index is the percentage of the maximum aerobic capacity (PMAC) used to perform the task, calculated by the formula [60]: PMAC $=$ (average HR during work-HR at rest)/(Expected maximum HR-HR at rest), the expected maximum $\mathrm{HR}=220$-age. $33 \%$ is an acceptable limit of PMAC for an eight-hour working day [60].

For arterial pressure evaluation, besides the systolic (PAS) and diastolic pressure (PAD), the mean arterial pressure (MAP) was calculated based on the formula proposed by Fox and Mathews [27] and McArdle et al. [52]: PAM=PD+1/3(PAS-PAD). Despite the high population variability, the "normal" measurements at rest expected for men and women are: $\mathrm{PAS}=120 \mathrm{~mm} \mathrm{Hg}$ and $\mathrm{PAD}=70$ to $80 \mathrm{~mm} \mathrm{Hg}$ [52], $\mathrm{PAM}=70+1 / 3(120-70)=86.6$ and $80+1 / 3(120$ - 80) $=93,3$. During exercise, PAS increases up to $200 \mathrm{mmHg}$ and PAD up to 79.1-93.4 $\mathrm{mmHg}$ [51], the expected PAM being 79.1+1/3(200- 79.1)=119.4 $\mathrm{mmHg}$ to $93.4+1 / 3(200-93.4)=128.93 \mathrm{mmHg}$.

Table 1 presents WP, PMCA and arterial pressure (PAS, PAD and PAM) data on the two dates, for both the I and C/W sectors. Mann-Whitney U test did not show statistical difference between the two sectors for WP and arterial pressure. Considering that work is heavier (due to load handling) at the I than at the
$\mathrm{C} / \mathrm{W}$ sector, it can be assumed that the cardiac outputs are similar due to the static work at the $\mathrm{C} / \mathrm{W}$.

Both in the I and C/W sectors, the Kuskal-Wallis test showed no statistical difference among the three shifts, on date 1, regarding WP and PMCA. However, on date 2 , in the I sector, there is a significant difference on the third $(p=0.063)$ and fourth $(p=0.082)$ measurements of WP what might be associated to the high temperatures registered on date 2 . The same test did not show significant difference between the measurements of the three shifts in the $\mathrm{C} / \mathrm{W}$ sector on date 2. However, the Friedman test showed significant difference in the first day (date 1) for shift 1 regarding WP $(p=0.041)$ and PMCA $(p=0.041)$. The second measurements of WP and PMCA are the lowest of the four measurements and the third is the highest. The reason for the lower WP and PMCA on date 1 is the lower temperature level, since it has direct impact on FC [48]. None of the shifts in both sectors exceeded the limits of 30-35 WP and 33\% of PMCA for continuous work in any evaluated date. It was expected that the arterial pressure were also statistically significant considering that it should follow HF behavior [38]. However, there is only difference on the third PAD measurement of date 1 , for the shift 1 of the $\mathrm{C} / \mathrm{W}$ sector.

Spearman correlation test showed arterial pressure and FC correlation $(\mathrm{p}=0.001)$ between HF and PAM only for the second measurement on date 1 and the first measurement on date $2(\mathrm{p}=0.018)$. Arterial pressure is lower in the $\mathrm{C} / \mathrm{W}$ sector in comparison with the I sector. Man-Whitney U test showed significant difference between PAS $(\mathrm{p}=0.022)$ and PAM $(\mathrm{p}=0.094)$ on the second measurement on date 2 , the values being lower in the $\mathrm{C} / \mathrm{W}$ sector. On the third evaluation on date 2, significant differences were found between PAS $(p=0.088)$, PAD $(p=0.025)$ and PAM $(p=0.026)$, all the values being lower in the $\mathrm{C} / \mathrm{W}$ sector. On the fourth evaluation on date 2 , there 
Table 1

Summary of the physiological data from 23 volunteers from the three shifts of the Imprint and Cutting/Welding sectors of the packaging manufacturer company

\begin{tabular}{|c|c|c|c|c|c|c|c|c|c|c|c|c|c|c|c|c|c|}
\hline \multirow[b]{3}{*}{ Sector } & \multirow[b]{3}{*}{ Shift/Date } & \multirow[t]{2}{*}{$\begin{array}{c}\text { WP } \\
(\mathrm{b} / \mathrm{min})\end{array}$} & \multirow[t]{3}{*}{$\begin{array}{c}\text { PCMA } \\
(\%) \\
\end{array}$} & \multirow[t]{2}{*}{$\begin{array}{c}\text { WP } \\
\text { (b/min) }\end{array}$} & \multirow[t]{2}{*}{ PCMA (\%) } & \multicolumn{2}{|c|}{$\begin{array}{c}\begin{array}{c}\text { PAS } \\
(\mathrm{mmHg})\end{array} \\
\end{array}$} & \multicolumn{2}{|c|}{$\begin{array}{c}\text { PAD } \\
(\mathrm{mmHg})\end{array}$} & \multicolumn{2}{|c|}{$\begin{array}{c}\text { PAM } \\
(\mathrm{mmHg})\end{array}$} & \multicolumn{2}{|c|}{$\mathrm{Na} / \mathrm{A} / \mathrm{s} / \mathrm{Na} / \mathrm{Ae}$} & \multicolumn{4}{|c|}{ Cortisol } \\
\hline & & & & & & & & & & & & & & start & end & start & end \\
\hline & & & & & & 1 & 2 & 1 & 2 & 1 & 2 & 1 & 2 & & & & \\
\hline \multirow{4}{*}{ Imprint } & 1 & 21.5 & 20.75 & 10.5 & 10.25 & 132.82 & 131.00 & 81.62 & 86.00 & 99.4 & 100.5 & 1.36 & 1.52 & 0.54 & 0.16 & 0.625 & 0.095 \\
\hline & 2 & 14.65 & 15.75 & 14.5 & 13.5 & 140.75 & 133.6 & 65.19 & 83.7 & 105.1 & 100.25 & 0.87 & 5.82 & 0.24 & 0.1 & 0.84 & 0.14 \\
\hline & 3 & 5.48 & 4.0 & 24.5 & 24.5 & 140.5 & 135.9 & 90.37 & 86.8 & 107.1 & 103.75 & 0.69 & 57.58 & 0.24 & 0.4 & 0.3 & 0.52 \\
\hline & mean & 13.88 & 13.50 & 16.50 & 16.08 & 138.02 & 133.50 & 79.06 & 85.50 & 103.87 & 101.50 & 0.97 & 21.64 & 0.34 & 0.22 & 0.59 & 0.25 \\
\hline \multirow{4}{*}{$\begin{array}{l}\text { Cutting/ } \\
\text { welding }\end{array}$} & 1 & 17.95 & 16.5 & 15.75 & 14.0 & 116.9 & 119.25 & 76.55 & 74.4 & 89.75 & 89.25 & 22.97 & 5.51 & 0.426 & 0.12 & 0.506 & 0.174 \\
\hline & 2 & 17.67 & 15,50 & 11.75 & 10.25 & 135.83 & 122.25 & 83.16 & 73.58 & 100.17 & 83.66 & 0.86 & 2.41 & 0.3 & 0.13 & 0.13 & 0.09 \\
\hline & 3 & 17.35 & 15.25 & 17.25 & 16.25 & 137.9 & 129.95 & 85.00 & 76.55 & 102.65 & 97.33 & 0.81 & 18.46 & 0.214 & 0.192 & 0.356 & 0.212 \\
\hline & mean & 17.66 & 15.75 & 14.92 & 13.50 & 130.21 & 123.82 & 81.57 & 74.84 & 97.52 & 90.08 & 8.21 & 8.79 & 0.31 & 0.15 & 0.33 & 0.16 \\
\hline
\end{tabular}

is also difference between PAD ( $\mathrm{p}=0.040)$ and PAM $(\mathrm{p}=0.041)$ of the two sectors, the values being always lower in the $\mathrm{C} / \mathrm{W}$ sector. Considering the differences occurred in different days, in different moments with different people, it can be concluded that the lower values of arterial pressure are due to the type of work carried out in the $\mathrm{C} / \mathrm{W}$ sector.

In work involving few muscles of the upper limbs, as is the case in the $\mathrm{C} / \mathrm{W}$ sector, it is expected an increase of AP due to the vessels constriction of the inactive muscles [10]. The more muscles are active in a dynamic work, as is the case in the I sector, the higher is the vessels dilation and the lower is the peripheral resistance, reflecting in the decrease of AP. However, in the $\mathrm{C} / \mathrm{W}$ sector, few upper muscles are involved, and there is isometric (static) work of the lower limbs to keep the prolonged standing up static position. As the work with the upper limbs has lower impact on the AP increase in comparison with the work of the lower limbs, one possible explanation for the AP decrease (and HF increase) in the $\mathrm{C} / \mathrm{W}$ sector is a AP reflex response to the long term standing up static position. This posture imposes that blood stays in the lower limbs, what leads to less blood return to the right side of the heart with consequent AP reduction. This finding is important as it indicates that the $\mathrm{C} / \mathrm{W}$ work imposes higher than normal pressure in the lower limbs, what might be a problem mainly for the workers with cardiovascular disorders such as varicose veins.

In the I sector, work is dynamic therefore blood return is activated by the workers movements, keeping $\mathrm{AP}$ at a normal level. Indeed, there is no increase in arterial pressure in the I sector, PAM tending to normal in the three shifts, what is consistent with dynamic work. The Kuskal-Wallis test showed no significant difference among the pressure measurements PAD, PAS and PAM in the four evaluations of the three shifts on the 2 dates.

\subsubsection{Type of workload based on catecholamine data: $\mathrm{Na} / \mathrm{A}(\mathrm{e}) / \mathrm{Na} / \mathrm{A}(\mathrm{s})$}

Since FC is an index of overall workload, Fibiger et al. [20] proposed that the type of load can be evaluated by the rate Nor-adrenaline/Adrenaline, the higher the rate, more physical being the load, considering that more adrenaline indicates more mental load while more nor-adrenaline indicates more physical load. Fibiger et al. [20] propose that when NA/A is higher than 5 the load is more physical while rates between 2 and 3 indicates more mental load. Some studies [19,33-35] used the rate Noradrenaline/Adrenaline at the start of the journey and Nor-adrenaline/Adrenaline at the end of the journey $(\mathrm{Na} / \mathrm{A}(\mathrm{s}) / \mathrm{Na} / \mathrm{A}(\mathrm{e}))$ to evaluate the type of predominant load in a given work journey. When the values are lower than 1, the load is considered to be mental $(\mathrm{M})$, while values higher than 1 indicate physical workload (P) [19]. The Kruskal-Wallis test did not show significant difference in the catecholamine data as a function of the shift of the two sectors in any of the collected dates. Because data were collected in two different dates, in some cases the workload was more mental in one date but more physical in another, therefore it was considered that there is no predominant workload, the work being both mental and physical (PM). There was no effect of worker characteristics on the results, the workload varying with the individual for a same task in the same shift and sector, what is in accordance with De Waard [18].

\subsection{Subjective analysis of workload}

Despite no statistical difference was found, the adapted NASA-TLX questionnaire (Table 2) showed that the workload is perceived as being higher in the I sector in comparison to the $\mathrm{C} / \mathrm{W}$ one, mainly in rela- 
tion to effort in the three shifts, temporal demand in shifts 1 and 3, performance in shift 2 and physical demand in shift 3. Considering the shifts, the Kruskal-Wallis test showed significant differences among physical demand $(\mathrm{p}=0.00716)$ and effort $(\mathrm{p}=0.0199)$, in the I sector, which are higher in shift 1 than in shift 2 . The differences can be explained by the production demand for large batches that is higher in shift 1 . In shifts 2 e 3 , the demand is for production of smaller batches. In the $\mathrm{C} / \mathrm{W}$ sector, the higher loads are effort in shifts 2 and 3, and performance in shift 2, although no significant differences were found in the results of this sector.
Although the literature emphasizes the difficulties of working during the night, this study shows that the stress of the unusual working schedule might be compensated by some characteristics of night work: lower temperatures, less noise, less managerial pressure (i.e. more autonomy) what makes it easier for the worker to cope with the shift, corroborating Verdier et al. [66]. Besides, following the Brazilian law [14], night work has the advantage of $20 \%$ increase in salary, often a good reason for choosing (or accepting) the unusual shift, in accordance with Monk [54]. $55.3 \%$ of the participants do not like shiftwork, $89.4 \%$ prefer fixed rather than rotating shifts (contrary to the proposal of

Table 2

Summary of the physiological and subjective results of the workload evaluation of 23 workers from the Imprint and Cutting/Welding sectors of the packaging manufacturer company

\begin{tabular}{|c|c|c|c|c|c|c|c|c|c|c|c|c|c|c|c|c|}
\hline \multirow[b]{2}{*}{ sector } & \multicolumn{7}{|c|}{ Physiological } & \multicolumn{3}{|c|}{ MA/Content* } & \multicolumn{5}{|c|}{ Adapted NASA TLX** } & \multirow[b]{2}{*}{$\begin{array}{c}\text { Total } \\
\text { Demand* }\end{array}$} \\
\hline & shift & $\begin{array}{c}\text { PAS } \\
(\mathrm{mmHg})\end{array}$ & $\begin{array}{c}\begin{array}{c}\mathrm{PAD} \\
(\mathrm{mmHg})\end{array} \\
\end{array}$ & $\begin{array}{c}\begin{array}{c}\text { PAM } \\
(\mathrm{mmHg})\end{array}\end{array}$ & WP (b/min) & PMAC (\%) & $\begin{array}{c}\mathrm{NA} / \mathrm{A}(\mathrm{s}) / \mathrm{NA} \\
/ \mathrm{A}(\mathrm{e})\end{array}$ & $\begin{array}{l}\text { Mental } \\
\text { Demand }\end{array}$ & $\begin{array}{l}\text { Physical } \\
\text { Demand }\end{array}$ & $\begin{array}{l}\text { Mental } \\
\text { Demand }\end{array}$ & $\begin{array}{l}\text { Physical } \\
\text { Demand }\end{array}$ & $\begin{array}{c}\text { Temporal } \\
\text { Demand }\end{array}$ & $\begin{array}{c}\text { Performanc } \\
\mathrm{e}\end{array}$ & Effort & $\begin{array}{c}\text { Level } \\
\text { Frustration }\end{array}$ & \\
\hline \multirow{3}{*}{ Imprint } & 1 & 132.82 & 83.86 & 99.95 & 23 & 14.25 & P & 12.24 & 10.53 & 1.98 & 2.67 & 2.27 & 1.41 & 3.02 & 0.9 & 12.29 \\
\hline & 2 & 137.17 & 74.5 & 102.7 & 14.57 & 14.62 & PM & 9.83 & 8.43 & 2.09 & 1.11 & 1.65 & 1.83 & 1.74 & 1.27 & 9.71 \\
\hline & 3 & 138.2 & 88.6 & 105.45 & 14.98 & 14.25 & P & 9.31 & 9.92 & 1.95 & 1.8 & 2.16 & 1.02 & 1.93 & 2.29 & 11.16 \\
\hline \multicolumn{2}{|c|}{ mean } & 136.06 & 82.32 & 102.70 & 17.52 & 14.37 & & 10.46 & 9.63 & 2.01 & 1.86 & 2.03 & 1.42 & 2.23 & 1.49 & 11.05 \\
\hline \multirow{3}{*}{$\begin{array}{l}\text { Cutting/ } \\
\text { Welding }\end{array}$} & 1 & 118.07 & 75.47 & 89.5 & 16.85 & 15.12 & $P$ & 8.18 & 8.3 & 1.98 & 1.47 & 1.18 & 2.06 & 2.37 & 1.02 & 10.12 \\
\hline & 2 & 129.04 & 78.37 & 91.91 & 14.71 & 12.97 & PM & 7.49 & 8 & 1.57 & 1.22 & 1.05 & 1.23 & 1.92 & 1.21 & 8.22 \\
\hline & 3 & 133.93 & 80.75 & 99.99 & 17.3 & 15.75 & $P$ & 9.32 & 9.51 & 1.64 & 1.28 & 1.35 & 1.5 & 2.08 & 1.46 & 9.34 \\
\hline \multicolumn{2}{|c|}{ mean } & 127.01 & 78.20 & 93.80 & 16.29 & 14.61 & & 8.33 & 8.60 & 1.73 & 1.32 & 1.19 & 1.60 & 2.12 & 1.23 & 9.23 \\
\hline
\end{tabular}

the night and shiftwork literature) and like their work. The fact that the circadian cycle of all workers in the nightshift did not adjust to the shift, as indicated by the cortisol evaluation, did not impact in the results.

\subsection{Comparison of physiological and subjective mea- surements of workload}

A summary of the physiological and subjective measurements of workload is presented in Table 2 . The Kruskal-Wallis test did not show significant difference between the physiological (Na/A(e)/ Na/A(s)) and subjective workload data (physical and mental demands evaluated by the adapted NASA-TLX and MA work content questionnaires) as a function of shift and/or sector. Therefore, the subjective and physiological data point in the same direction.

Spearman correlation test showed a positive correlation $(\mathrm{p}=0.016)$ between physical effort (MA questionnaire) and physical demand (NASA TLX ques tionnaire) in the I sector. In shifts 2 and 3 of both I and $\mathrm{C} / \mathrm{W}$ sectors there are a positive correlation bet- ween physical effort and physical demand $(p=0.041$ in shift 2 and $p=0.042$ in shift 3 ). In shift 3 , there is a positive correlation $(\mathrm{p}=0.0026)$ between mental and physical efforts and negative correlation $(\mathrm{p}=0.049)$ between physical and mental demands of the adapted NASA-TLX questionnaire.

\section{Conclusion}

This article presented a study on the workload imposed by the work in the Imprint and Cutting/Welding sectors of a packaging manufacturer company that operates in three fixed shifts.

Workload was evaluated by physiological (urinary catecholamine; heart frequency and arterial pressure) as well as subjective tools (adapted NASA-TLX and MA Content questionnaires). Physiological data were obtained from 23 volunteers (10 workers from the Imprint sector and 13 workers of the Cutting/Welding sector) in two dates, and the questionnaires were re- 
sponded by the 85 participants (42 from Imprint and 43 from the Cutting/Welding sector).

The statistical results did not show significant differences in workload between the sectors. The work in the Imprint sector demands more physical effort (due to load handling) in comparison to the Cutting/Welding one, but the latter involves high static load what makes the overall workload the same. The physiological parameters varied with the individual and were consistent with the subjective workload evaluation. The arterial pressure of the workers from the Cutting/Welding sector did not follow the heart frequency, on the contrary, it decreased as heart rate increased pointing out that the static standing up posture adopted during all journey imposes a circulatory constraint due to the resistance of the returning blood flow what can lead to serious vascular problems.

Considering the shifts, there was significant difference only in relation to physical demand and effort in the Imprint sector. Their values are higher in shift 1 than in shift 2 , what can be explained by the production demand for large batches that is higher in shift 1 . Also, there was effect of temperature on the results from the Imprint sector, the highest workloads being measured in two moments when temperature was too high.

The physiological parameters of urinary catecholamine and salivary cortisol were consistent with the workers biological clock showing that none of them changed his/her biological cycle to accommodate to the time of the shift schedule. Although none of the workers likes shiftwork, they prefer to work in fixed shifts so they can better adjust their personal lives. The night shift workers like the extra payment for night shift, another social effect that probably reduces the burden of shiftwork.

There was no significant difference between the physiological and subjective results, making it clear that subjective parameters are as good as the physiological ones to evaluate workload. Workload is dependent on the type of effort imposed by the work but is also a subjective experience, varying with the individual who can evaluate his/her effort as accurately as his/her physiological response to the workload imposed.

\section{References}

[1] M.R Ahasan, G. Mohiuddin and A Khaleque, Psychosocial implications of shift work: a case study, Work Study 51 (3) (2002): 116-120.
[2] T.Akerstedt, Psychological and psycho-physiological effects of shift work, Scan. J. Work, Environ. and Health, Vol. 16 No. 1 (1990), pp. 67-73.

[3] T. Akerstedt, Wide awake at odd hours. Shift work, time zones and burning the midnight oil, Swedish Council for Work Life Research, Stockholm, 1996.

[4] T. Akerstedt, Shift work and disturbed sleep/wakefulness, Sleep Medicine Reviews, 2 (2) (1998), 117-128.

[5] T. Akerstedt, Shift work and disturbed sleep/wakefulness, Occupational Medicine, 53 (2003), 89-94.

[6] T. Akerstedt and G. Kecklund, Work hours, sleepiness and accidents, Stress Research Reports, Karolinska Institute/Proceedings and abstracts, number 248, 1994.

[7] T. Akerstedt, P. Fredlund, M. Gilbert and B. Jonsson, Work load and work hours in relation to disturbed sleep and fatigue in a large representative sample, Journal of Psychosomatic Research, 53 (1) (2002), 585-588.

[8] T. Akerstedt, G. Kecklund and S.E. Johansson, Shift work and mortality, Chronobiol. Int. 21:1055 - 1061, 2004.

[9] S. Al-Naimi, S.M. Hampton, P. Richard, C. Tzung and L.M. Morgan, Postprandial metabolic profiles following meals and snacks eaten during simulated night and day shift work, Chronobiol. Int. 21:937-947, 2004

[10]P. Astrand and K. Rodahl, Textbook of work physiology: physiological bases of exercise, 3. ed, New York, McGrawHill, 1986.

[11]J. R. Baratto, L. B. de M Guimarães and Ä. M. O. Sant'Anna, Avaliação da carga de trabalho no tratamento de encomendas, in: L. B. de M. Guimarães (org.) Macroergonomia: aplicação em produtos e serviços. Chapter 4.2, p. 1- 35, 2010.

[12]P. C. B. Bento, Qualidade do sono, das relações sociais e da saúde, de acordo com a percepção dos trabalhadores em turno e noturno. Dissertation (MEng) Federal University of Rio Grande do Sul, Porto Alegre. 2004.

[13]Brasil, CLT Consolidacao das Leis do Trabalho, 1943(a), Lei 5.452 de 01.05.1943 - C.L.T.;artigos 189 e 192 NR15 Anexo 3. Publicação D.O.U. Portaria GM n. ${ }^{\circ} 3.214$, de 08 de junho de 1978.

[14] Brasil, CLT Consolidacao das Leis do Trabalho, 1943(b), Lei 5.452 de 01.05.1943 - C.L.T.; Decreto-lei 9.666 de 28.08.1946; Lei 5.889 de 08.06.1973; Decreto 73.626 de 12.02.1974; Súmulas STF 213, 214 e 313,

[15] Costa, G. Saúde e trabalho em turnos e noturno. In: Fischer, F.M., Moreno, C.R.C., Rotemberg, L. (Eds) Trabalho em turnos e noturno. São Paulo: Atheneu, 2004, p.79-98.

[16]G. Costa, T. Akersted, F. Nachreiner, F. Baltieri, J. Carvalhais, S. Folkard, M.F. Dresen, C. Gadbois, J. Gartner, H.G. Sukalo, M. Harma, I. Kandolin, S. Sartori and J. Silverio, Flexible working hours, health, and well-being in Europe: Some considerations from a SALTSA project. Chronobiol. Int. 21:831-844, 2004.

[17] S.M. Couto, A influência da matutinidade/vespertinidade na suscetibilidade das demandas ergonômicas em operadores de teleatendimento que trabalham em turnos. Dissertation (MEng). Federal University of Rio Grande do Sul, Porto Alegre, 2003.

[18]D. De Waard, The Measurement of Driver's Mental Workload. Thesis (PhD) University of Groningen, Centre for Environmental and Traffic Psychology, Haren.Holand, 1996.

[19]R. L. Diniz, Avaliação das Demandas Física e Mental no Trabalho do Cirurgião em Procedimentos Eletivos. Thesis (Dr.) Federal University of Rio Grande do Sul, Porto Alegre, 2003.

[20]W. Fibiger, G. Singer and A. Miller, Relationships between catecholamines in urine and physical and mental effort. International Journal of Psychophysiogy. 1(1984), 325 - 333. 
[21]F. M. Fischer, Condições de trabalho e de vida em trabalhadores do setor petroquímico. Thesis (Livre-Docência), Faculdade de Saúde Pública da Universidade de São Paulo, 1990.

[22]F. M. Fischer, A. Berwert, A.C. Bruni, C.R.C. Moreno, R.L. Fernandez and C. A Riveielo, organização do trabalho em turnos e repercussões no sono de trabalhadores petroquímicos. Revista Brasileira de Saúde Ocupacional, 21(78) (1993), 3341.

[23]F. M. Fischer, A. C. Bruni, A. Berwerth, C.R.C. Moreno, R. L. Fernandez and C. Riviello, Do weekly and fast rotating shiftwork schedules differentially affect duration and quality of sleep? International Archives of Occupational Environmental Health, 69: 354-360, 1997.

[24]F. M. Fischer, C.R.C. Moreno, F.N.S. Borges and F.M. Louzada, Implementation of 12 hour shifts in a Brazilian petrochemical plant: impact on sleep and alertness. Chronobilogy International, 17 (2000), 521-537.

[25]F. M. Fischer, J.C. Scatena and A. de C Bruni, Effects of sleep and leisure time under continuous shiftwork schedules of subway workers, in: A.Ogisnki, J. Pokorski and J. Ruten-franz, eds, Contemporary advances in shiftwork research, Theoretical and practical aspects in the late eighties, pp. 375-384. Medical Academy, Krakow, 1987.

[26] S. Folkard, D.A. Lombardi, Toward a "risk index" to assess work schedules, Chronobiol Int. 21(2004), 1063 - 1072.

[27]E. Fox and D. Mathews, Bases fisiologicas da educacao fisica e dos desportos, 3 ed, Rio de Janeiro, Guanabara Koogan, p.173-177, 1986 .

[28]Fundacentro. NHO01-, 2001. Norma de Higiene Ocupacional. Procedimento Técnico para Avaliação Ocupacional da Exposição ao Ruído. MTE - FUNDACENTRO.

[29]E. Grandjean, Fitting the task to the man: an ergonomic approach, London, Taylor \& Francis, 1981.

[30]L. B. de M. Guimarães, Abordagem ergonômica: o método macro. in: Guimarães, L. B. de M (org.) Ergonomia de Processo, 3. ed, Porto Alegre, FEENG, 1999.

[31] L. B. de M. Guimarães, Relatório de avaliação ergonômica em uma aciaria do Rio Grande do Sul, 2003. Not publihed.

[32]L. B. de M Guimarães and R. L. Diniz, 2001. Adaptation of the NASA-TLX questionnaire, First used in: R.L. Diniz, Avaliação das Demandas Física e Mental no Trabalho do Cirurgião em Procedimentos Eletivos. Thesis (Dr.) Federal University of Rio Grande do Sul, Porto Alegre, 2003.

[33]L. B. de M. Guimarães, D. Fischer, J. Bittencourt, P. I. H. de Avaliação da carga de trabalho de eletricistas em três sistemas para subida em poste, in: Anais...ABERGO 2004, Fortaleza. Associacao Brasileira de Ergonomia, 2004.

[34]L. B. de M. Guimarães and Â. M. O Sant'Anna, Avaliação da carga de trabalho de eletricistas de linha viva com base em parâmetros cognitivos e fisiológicos, in: 16 Sinape Simpósio Nacional de probabilidade e estatística, Caxambu - MG. CDROM. São Paulo, ABE Associação Brasileira de Estatística, 2004.

[35] L. B. de M. Guimarães, T. A. Saurin, Evaluation of the workload imposed to electricians based on cognitive and physiological parameters, in: International Ergonomics Association Conference. Maastricht, IEA, 2006.

[36]A.C. Guyton, Basic Human Physiology: Normal Function and Mechanisms of Disease, Philadelphia, Saunders, 1977.

[37] J. Hennig, P. Kieferdorf, C. Moritz, S, Huwe and P. Netter, Changes in cortisol secretion during shiftwork: implications for tolerance to shiftwork? Ergonomics, 41 (5) (1998): $610-$ 621.

[38]E. Hietanen, Cardiovascular responses to static exercise. Scand J Work Environ Health 10 (1984), 397-402,
[39] M. Ingre, G. Kecklund, L. Akerstedt, L. kecklund, Varia-tion in sleepiness during the early morning shifts: A mixed model approach to an experimental field study of train drivers, Chronobiol. Int. 21 (2004), 973-990.

[40]B. Jansen, W.G.M. Vos and E.G. DE Haan, Compensation for shift work. Contributions to best (bulletin of European shift work topics), Dublin: European Foundation for the Improvement of Living and Working Conditions, 1990.

[41]P. Knauth, The design of shift systems. Ergonomics, 36 (1993), 15-28.

[42]P. Knauth, Modelos e tendências de jornada de trabalho flexíveis em setores de produção e serviços: o caso da Europa, in: F.M. Fischer, C.R.C. Moreno, L. Rotemberg, eds, Trabalho em turnos e noturno, São Paulo, Atheneu, p.19-30. 2004.

[43]P. Knauth, Extended Work Periods, Industrial Health 45 (2007), 125-136.

[44]P. Knauth, E. Schönfelder and S. Hornberger, Compensation for shift work, Contributions to best (bulletin of European shift work topics), Dublin: European Foundation for the Improvement of Living and Working Conditions, 1990.

[45]A. Knutsson, Shiftwork and cardiovascular disease, National Institute for Psychosocial Factors and Health, Karolinska Institute, Stockoholm, 1989.

[46]A. Knutsson, Methodological aspects of shift-work research Chronobiol. Int. 21 (2004), 1037-1047.

[47]A. Knutsson, N. Hammar and B. Karisson, Shift workers mortality scrutinized, Chronobiol. Int. 21(2004), 1049 - 1053.

[48] K.H.E. Kroemer and E. Grandjean, Manual de ergonomia: adaptando o trabalho ao homem, $5^{\mathrm{a}}$ ed, Porto Alegre, Bookman, 2005.

[49]K. Lee, Self-reported sleep disturbances in employed wom-en, Sleep, 15 (1992), 493-498.

[50]M.G. Lenne, F. Dwyer, T.J Triggs, S. Rajaratnam and J.R. Redman, The effects of a nap opportunity in quiet and noisy environments on driving performance, Chronobiol, Int. 21 (2004), $991-1001$.

[51]B. G. Makowski, L.B. de M. Guimarães, L. Ballardin, Análise do cronotipo dos motoristas e alocação de turnos em uma transportadora de produtos perigosos, Anais ... ABERGO, 2006. Associacao Brasileira de Ergonomia, 2006.

[52]W.D. McArdle, F.I. Katch and V.L. Katch, Sistema en-docrino e exercicio. in: W.D. MacArdle, F.I. Katch and V.L Katch, (eds.) Fisiologia do Exercicio: energia, nutricao e desempenho humano, 4 ed, Rio de Janeiro, Guanabara Koogan, p. 339-367, 1996.

[53]M.C.R. Menezes, M.L.N. Pires, A.A. Benedito-Silva and S. Tufik, Sleep parameters among offshore workers: An initial assessment in the Campos basin, Rio De Janeiro, Brazil. Chronobiol, Int. 21 (2004), 889-897.

[54]T.H. Monk, Shiftworker performance, Occupational Medicine: state of the art reviews, 5 (2) (1990), 183-198.

[55]C.R.C. Moreno, F.A. Carvalho, C. Lorenzi, L.S. Matuzaki, S. Prezotti, P. Bighetti, F.M. Louzada and G.Lorenzi-Filho, High risk for obstructive sleep apnea in truck drivers esti-mated by the Berlin questionnaires: Prevalence and associated factors, Chronobiol. Int. 21 (2004), 871-879.

[56] A. Nakata, T. Haratani, M. Takahashi, N. Kawakami, H. Arito, F. Kobayashi, Y. Fujioka, S.Fukui and G. Araki, As-sociation of sickness absence with poor sleep and depressive symptoms in shift workers, Chronobiol. Int. 21 (2004), 899-912.

[57]I.C. Pasqua and C.R.C. Moreno, The nutritional status and eating habits of shift workers: A chronobiological approach, Chronobiol, Int. 21 (2004), 949-960.

[58]L.F. Portella, L. Rotenberg and W.Waissmann, Self-reported health and sleep complaints among nursing personnel working 
under $12 \mathrm{~h}$ night and day shifts, Chronobiol, Int. 21 (2004), 859-870.

[59] S.M.W. Rajaratnam and C.B. Jones, Lessons about sleepi-ness and driving from the Selby rail disaster case: R v Gary Neil Hart. Chronobiol. Int. 21 (2004), 1073-1077.

[60]S. Rodgers, Ergonomic design for people at work, v.2, New York, John Wiley \& Sons, 1986

[61]L. Rotenberg, Trabalhando de noite e dormindo de dia regularidade do sono e adaptação psicológica de operárias do turno noturno, São Paulo, Thesis (Dr), 1997.

[62]L. Rotenberg, Medidas de intervenção: abordando a questão do lado dos trabalhadores, empresas e usuários. in: F.M Fischer, C.R.C. Moreno, L. Rotemberg, eds, Trabalho em turnos e noturno, São Paulo, Atheneu, 2004, p.53-63.

[63] L. Rotenberg, L.F. Portela, W.B. Marcondes, C. Moreno, C.P Nascimento, Gênero e trabalho noturno: sono, cotidiano e vivências de quem troca a noite pelo dia, Cad. Saúde Pública, 17 (2001), 639-649.
[64]H.E.R. Santos, M.T. De Mello, M. Pradella-Hanninan, L. Luchesi, M.L.N Pires and S. Tufik, Sleep and sleepiness among Brazilian shift-working bus drivers. Chronobiol, Int. 21 (2004), 881-888.

[65]C. Teiger, A. Laville and M. Lortie, Travailleurs de nuits permanents, rythmescircadiens et mortalité, Le Travail Humain, 44 (1) (1981), 71-92.

[66]F. Verdier, B. Barthe and Y. Quéinnec, Organização do trabalho em turnos: concentrando-se na análise ergonômica ao longo das 24 horas, in: F.M. Fischer, C.R.C Moreno and L. Rotemberg, eds, Trabalho em turnos e noturno, São Paulo, Atheneu, 2004, p.137-157.

[67] A.M. Williamson and A-M Feyer, Causes of accidents and the time of the day. Work e Stress, Vol. 9, (2/3) (1995), 158-164. 